Article

\title{
Effects of Rhodomyrtus tomentosa Extract on Killing Activity of Human Neutrophils and Membrane Integrity of Enterohaemorrhagic Escherichia coli O157:H7
}

\author{
Jutharat Hmoteh ${ }^{1,2}$, Khadar Syed Musthafa ${ }^{2}$, Rattanaruji Pomwised ${ }^{1}$ \\ and Supayang Piyawan Voravuthikunchai ${ }^{1,2, *}$ \\ 1 Department of Microbiology, Faculty of Science, Prince of Songkla University, Hat Yai, Songkhla 90112, \\ Thailand; bebegamalar@gmail.com (J.H.); rattanaruji.p@psu.ac.th (R.P.) \\ 2 Excellent Research Laboratory on Natural products, Faculty of Science and Natural Product Research Center \\ of Excellence, Prince of Songkla University, Hat Yai, Songkhla 90112, Thailand; \\ syed_musthafa@rediffmail.com \\ * Correspondence: supayang.v@psu.ac.th; Tel.: +66-74-288-340; Fax: +66-74-446-661
}

Academic Editors: Anake Kijjoa, Bungorn Sripanidkulchai and Maria Emília de Sousa Received: 20 February 2016; Accepted: 23 May 2016; Published: 27 May 2016

\begin{abstract}
Enterohaemorrhagic Escherichia coli (E. coli) O157:H7 is one of the most virulent causative agents of foodborne disease. Use of antibiotics for the treatment against E. coli O157:H7 infection leads to hemolytic uremic syndrome. The present study evaluated the potential of ethanolic leaf extract of a medicinal plant, Rhodomyrtus tomentosa in enhancing the killing activity of human neutrophils against E. coli O157:H7. In addition, the effects of the extract on membrane permeability of the organisms were studied. In the killing assay, percentage survival of the bacterial cells after being exposed to human neutrophils in the presence of various concentrations of the extract were determined. At $45 \mathrm{~min}$, percentage survival of E. coli O157:H7 and E. coli ATCC 25922 after treated with neutrophils in the presence of the extract at $125-250 \mu \mathrm{g} / \mathrm{mL}$ was $58.48 \%-50.28 \%$ and $69.13 \%-35.35 \%$, respectively. Furthermore, upon treatment with $R$. tomentosa at $250 \mu \mathrm{g} / \mathrm{mL}$ uptake of crystal violet by $E$. coli O157:H7 and E. coli ATCC 25922 was increased to $40.07 \%$ and $36.16 \%$, respectively. Therefore, it is suggested that the extract exhibited dual effects as immunostimulant and membrane permeabilizing agent perhaps resulted in enhancing the killing activity of neutrophils against the organisms.
\end{abstract}

Keywords: Rhodomyrtus tomentosa; human neutrophils; Escherichia coli O157:H7; immunomodulatory activity; membrane integrity

\section{Introduction}

Enterohaemorrhagic Escherichia coli O157:H7 is a Gram-negative human pathogen that causes bloody diarrhea as well leads to severe abdominal cramps in the infected patients. Moreover, production of Shiga toxin could lead to hemorrhagic colitis in humans [1,2]. Although conventional antimicrobial treatment is generally prescribed for the infection caused by various pathogenic bacteria, use of antibiotics to treat enterohaemorrhagic E. coli O157:H7 infection is not generally recommended due to an increased risk of hemolytic uremic syndrome [3]. Therefore, suitable alternative measures for the prevention of infections caused by E. coli O157:H7 are urgently required [4].

Plants are valuable sources of pharmacologically important bioactive metabolites and, therefore, targeting the resource is one among several interesting alternative strategies to control enterohaemorrhagic E. coli O157:H7 infection [5,6]. Utilization of plant materials as an immunostimulant to increase the activity of the host immune system against a pathogenic organism 
is an interesting approach to eliminate microbial infection within the host system. For example, a polysaccharide fraction from Solanum nigrum Linn [7] and Coffea arabica L. seed extract [8] was reported previously to activate the host immune response. In addition, it has been well demonstrated that the bacterial cell membrane is considered as a defensive barrier known to protect the pathogenic bacteria from environmental stress, and, therefore, plant extracts possessing an ability to alter bacterial membrane integrity is another strategy to make the pathogen more susceptible to the killing activity of host immune cells or antimicrobials (plant derived drugs) [9,10]. In view of this point, plants exhibiting immunostimulatory effects or have an ability to alter membrane integrity could be exploited to eliminate E. coli O157:H7 infections.

Rhodomyrtus tomentosa (Aiton) Hassk. is a medicinal plant belonging to the Myrtaceae family. The plant has been utilized for the remedy of various infectious diseases including urinary tract infection [11], diarrhea [12], and dysmenorrhea [13]. Furthermore, leaf extract of the plant demonstrated various biological activities including antioxidant [14,15], antibacterial [16,17], and antibiofilm properties [18]. Therefore, considering the potential of $R$. tomentosa extract, in the present study, an attempt was made to validate the effect of the extract in enhancing the killing activity of human neutrophils against E. coli O157:H7. Besides, effects of the extract on membrane integrity of the pathogen were evaluated.

\section{Results and Discussion}

\subsection{Effects of R. tomentosa Extract on Killing Activity of Neutrophils}

Immunostimulatory activity of plants in enhancing the killing effect of the host immune cells is an attractive approach to overcome the usage of antibiotics in controlling the infection caused by pathogenic bacteria $[9,10]$. Therefore, in the present study, potential of the ethanolic leaf extract of $R$. tomentosa was evaluated for its ability in increasing killing activity of human neutrophils against E. coli O157:H7. The percentage survival of E. coli after exposed to neutrophils in the presence of the extract is given in Figure 1A and B. It was observed that the extract alone at the tested concentrations of $62.5-250 \mu \mathrm{g} / \mathrm{mL}$ had no direct killing activity on the organisms. However, the extract enhanced the killing activity of neutrophils towards E. coli. At $30 \mathrm{~min}$, the extract at $62.5-250 \mu \mathrm{g} / \mathrm{mL}$ showed a moderate effect in enhancing the killing activity of neutrophils against both E. coli strains. However, a significant increase in the activity of neutrophils was observed after 45 and $60 \mathrm{~min}(p<0.05)$. At $45 \mathrm{~min}$, survival percentage of E. coli O157:H7 and E. coli ATCC 25922 when exposed to neutrophils in the presence of $62.5,125$, and $250 \mu \mathrm{g} / \mathrm{mL}$ of the extract were $94.15 \%, 58.48 \%, 50.28 \%$, and $73.15 \%, 69.13 \%$, and $35.35 \%$, respectively. Similarly, at $60 \mathrm{~min}$, survival percentage of E. coli O157:H7 and E. coli ATCC 25922 after being incubated with neutrophils in the presence of the same concentrations of the extract was $59.91 \%, 50.34 \%, 40.15 \%$ and $78.79 \%, 58.46 \%$, and $47.02 \%$, respectively. In the earlier study, it was demonstrated that DMSO up to $1 \%$ did not affect the killing activity of human neutrophils against E. coli [19]. In the present work, the solvent was used at the highest concentration of $0.5 \%(v / v)$ for control and treatment samples. From the results of cell survival assay, the killing activity of neutrophils increased with the increased addition of the extract. Therefore, it is envisaged that the solvent at the tested percentage did not interfere with the observed effects with neutrophils and demonstrated the ability of $R$. tomentosa extract to enhance the killing activity of human neutrophils against $E$. coli. In the earlier studies, other plant resources have been reported to enhance the activity of host immune cells against pathogenic organisms. Serafino et al. [20] reported that, upon treatment with Eucalyptus essential oil, the phagocytic ability of macrophages increased towards Staphylococcus aureus. In another study, iridoids fraction obtained from methanol extract of Barleria prionitis enhanced the intracellular killing activity of neutrophils against Candida albicans [10]. 
A

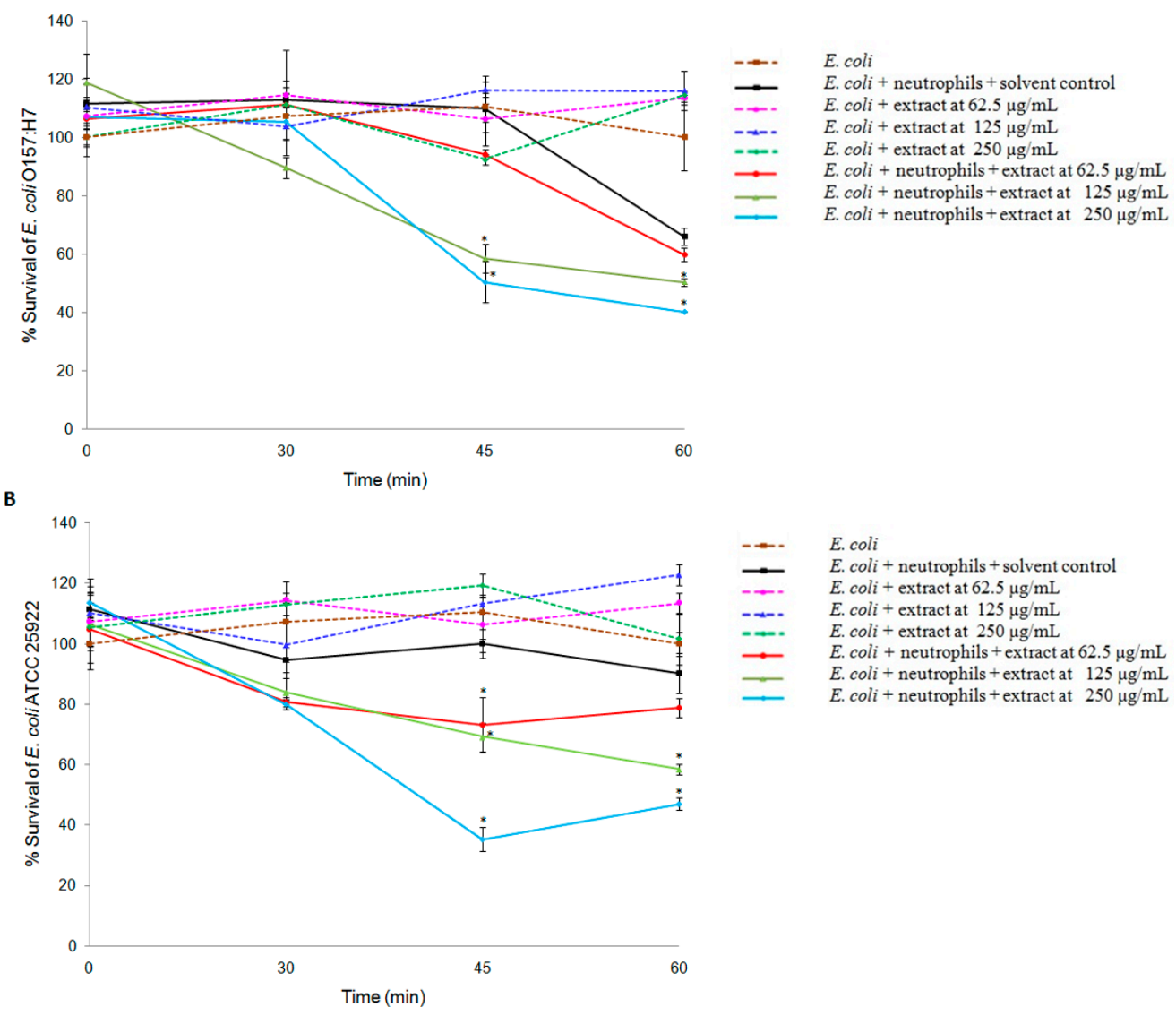

Figure 1. Effects of R. tomentosa extract on the killing activity of human neutrophils against Escherichia coli O157:H7 RIMD 05091078 (A) and E. coli ATCC 25922 (B). The bacterial cells were exposed to neutrophils in the absence and presence of $R$. tomentosa extract $(62.5-250 \mu \mathrm{g} / \mathrm{mL})$. Escherichia coli cells in the presence of the extract $(62.5-250 \mu \mathrm{g} / \mathrm{mL})$ alone were also maintained. Dimethyl sulfoxide $(0.5 \% v / v)$ was used as solvent control. The percentage survival of the organisms was determined at 0 , 30,45 , and $60 \mathrm{~min}$. Data are expressed as mean \pm standard error of the mean from two independent experiments. Each measure was performed in triplicate. * Statistical significance at $p<0.05$.

\subsection{Effects of R. tomentosa Extract on Membrane Integrity of E. coli}

Membrane permeability or integrity plays a critical role as a barrier in Gram-negative bacteria which protects the bacterial cells from the action of antimicrobial compounds $[9,10]$. Alteration in the membrane permeability could lead to easy passage of antimicrobial drugs into the cells resulting cell death $[9,10,21,22]$. In addition, defects in the membrane integrity may increase the susceptibility of the bacterial cells to host immune attack. In the present study, since the extract alone at the tested concentrations did not produce any considerable effects on the survival of $E$. coli cells, we evaluated the possible impact of $R$. tomentosa extract against the organisms by membrane permeability assay at the time intervals as those used in a similar set up mentioned in cell survival assay. It was observed that, upon treatment with the extract, uptake of crystal violet by the cell membrane of the organisms was significantly increased. Crystal violet uptake by E. coli O157:H7 and E. coli ATCC 25922 after $8 \mathrm{~h}$ was $4.89 \%$ and $1.95 \%$, respectively. However, upon being treated with the extract at $62.5-250 \mu \mathrm{g} / \mathrm{mL}$, uptake of the dye was $24.43 \%-40.07 \%$ in E. coli O157:H7 and $22.48 \%-36.16 \%$ in E. coli ATCC 25922. Even after short time exposure to $R$. tomentosa extract, the organisms showed alteration in their membrane permeability. The uptake of dye by E. coli O157:H7 at the similar time interval mentioned in the cell survival assay at 30,45 , and $60 \mathrm{~min}$ after the extract treatment at $62.5-250 \mu \mathrm{g} / \mathrm{mL}$ was $8.67 \%-14.67 \%$, 
8.00\%-24.00\%, and 18.47\%-21.02\%, respectively. Similarly, the uptake of dye by E. coli ATCC 25922 at 30,45 , and $60 \mathrm{~min}$ after the extract treatment at $62.5-250 \mu \mathrm{g} / \mathrm{mL}$ was $12.00 \%-22.00 \%, 8.67 \%-18.00 \%$, and $19.11 \%-24.20 \%$, respectively (Figure $2 \mathrm{~A}, \mathrm{~B}$ ).

A

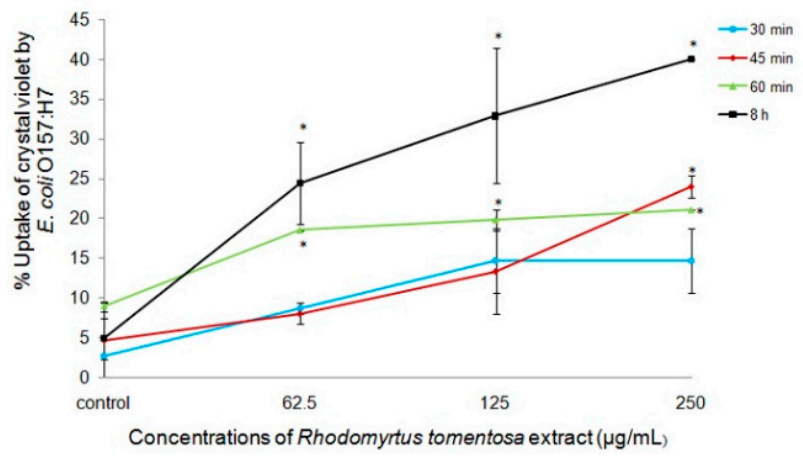

B

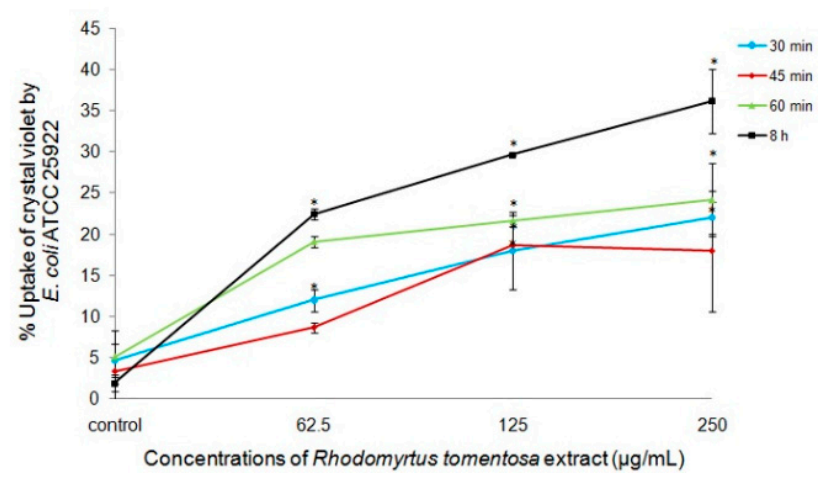

Figure 2. Effects of $R$. tomentosa extract on membrane permeability of Escherichia coli O157:H7 RIMD 05091078 (A) and E. coli ATCC 25922 (B) Crystal violet uptake by E. coli at 30, 45, $60 \mathrm{~min}$, and $8 \mathrm{~h}$ after treated with the extract at $62.5,125$, and $250 \mu \mathrm{g} / \mathrm{mL}$ was determined. Dimethyl sulfoxide $(0.5 \% v / v)$ was used as the solvent control. Data are expressed as mean \pm standard error from two independent experiments. Each measure was performed in triplicate. ${ }^{*}$ Statistical significance at $p<0.05$.

Therefore, it is demonstrated that the extract exhibited membrane permeabilizing activity rather than antibacterial activity at the tested concentrations, and resulted in the alteration of membrane integrity of E. coli. The attained result is in accordance with the previous study, in which membrane permeability of E. coli was disrupted after being treated with corilagin; a tannin group of compound resulted in increased uptake of crystal violet dye [22]. In another report, eugenol, a phytochemical from clove essential oil affected the membrane integrity of S. aureus [21]. We would also like to mention here that in our previous report, an acylphloroglucinol component, rhodomyrtone from the leaf extract of $R$. tomentosa showed immunomodulatory effects on THP-1 human monocyte cell line leading to enhanced killing of methicillin-resistant Staphylococcus aureus [23]. Therefore, it is anticipated that the extract possesses both membrane permeabilizing as well as immunomodulatory properties resulting in the increased susceptibility of E. coli cells to immune cell attack.

\section{Experimental Section}

\subsection{Pathogens Used and Culture Conditions}

Enterohaemorrhagic Escherichia coli O157:H7 RIMD 05091078 and E. coli ATCC 25922 were used as target strains. The strains were cultured in tryptic soy broth (TSB, Difco, Detroit, MI, USA) at $37^{\circ} \mathrm{C}$ for $18 \mathrm{~h}$. After incubation, the cells were pelleted at $2000 \times g$ for $7 \mathrm{~min}$, washed twice with phosphate buffer 
saline (PBS) (pH 7.4). The cell pellet was suspended in Roswell Park Memorial Institute 1640 medium (RPMI-1640, Sigma-Aldrich, St. Louis, MO, USA) and used for opsonization.

\subsection{Preparation of $R$. tomentosa Leaf Extract}

Rhodomyrtus tomentosa leaves were collected in April, 2013 from Sadao District, Songkhla Province in the southern part of Thailand. The collected samples were dried, ground into a powder, and then soaked with $95 \%$ ethanol for seven days. The ethanol layer was collected and evaporated to complete dryness under a rotary evaporator. The dried ethanolic extract was dissolved in $100 \%$ dimethyl sulfoxide (DMSO, Merck, Darmstadt, Germany).

\subsection{Serum Preparation and Opsonization}

Fresh serum was obtained from normal AB blood group donors. The bacterial cell suspension in RPMI-1640 medium was incubated with $10 \% \mathrm{AB}$ serum for $30 \mathrm{~min}$ at $37^{\circ} \mathrm{C}$. After incubation, the cell suspension was centrifuged at $2000 \times g$ for $10 \mathrm{~min}$ and washed twice with PBS. The cell density was adjusted to $10^{8} \mathrm{cfu} / \mathrm{mL}$ using RPMI 1640 medium. The numbers of opsonized cells were counted using a haemocytometer.

\subsection{Isolation of Human Neutrophils}

The buffy coat of healthy volunteers was obtained from the Blood bank of Songklanagarind hospital, and added with 6\% dextran (Fluka, Buchs, Switzerland). The mixture was gently shaken and allowed to stand at room temperature for $1 \mathrm{~h}$ to sediment erythrocytes. Leukocytes from the upper layer were transferred to a sterile centrifuge tube. The protocol of Histopaque-1.077 (Sigma-Aldrich) was used with slight modification for the isolation of neutrophils. Briefly, leukocytes were layered in Histopaque-1.077 solution and centrifuged at $700 \times \mathrm{g}$ for $35 \mathrm{~min}$ at $20^{\circ} \mathrm{C}$ to isolate neutophils. After the recovery, the viability and purity of the neutrophils were determined by trypan blue (Difco) exclusion assay [24] and Wright Giemsa stain (Sigma-Aldrich), respectively. The viability and purity of the neutrophils were $\geqslant 98 \%$ and $\geqslant 95 \%$, respectively.

\subsection{Cell Survival Assay}

The assay was performed by following the previously described method [10] with slight modification. In brief, $R$. tomentosa extract (stock solution-50 mg extract/mL DMSO) was double diluted in $1.5 \mathrm{~mL}$ eppendorf tubes containing $100 \mu \mathrm{L}$ RPMI medium to yield concentrations ranging from 250 to $62.5 \mu \mathrm{g} / \mathrm{mL}$. One hundred $\mu \mathrm{L}$ of neutrophils $\left(10^{6}\right.$ cells $\left./ \mathrm{mL}\right)$ were added to each tube and finally $100 \mu \mathrm{L}$ of the opsonized suspension of E. coli cells were added. The tube containing only neutrophils and E. coli along with the respective solvent was maintained as the control. In both control and treatment set up, the highest concentration of DMSO used was $0.5 \%(v / v)$. The tubes were incubated at $37^{\circ} \mathrm{C}$ for $30,45,60 \mathrm{~min}$ with gentle shaking to expose $E$. coli to the extract and neutrophils. After incubation, $10 \mu \mathrm{L}$ of the treated and untreated E. coli cell suspension was plated on tryptic soy agar and the colony forming units per milliliter $(\mathrm{cfu} / \mathrm{mL})$ was determined after incubation at $37^{\circ} \mathrm{C}$, overnight.

\subsection{Membrane Permeability Assay}

Effects of $R$. tomentosa extract on the integrity of E. coli were determined by membrane permeabilizing assay using crystal violet stain. The pathogen $\left(10^{8}\right.$ cells $\left./ \mathrm{mL}\right)$ was incubated with the extract at $62.5,125$, and $250 \mu \mathrm{g} / \mathrm{mL}$ for 30,45 , and $60 \mathrm{~min}$, and $8 \mathrm{~h}$ at $37^{\circ} \mathrm{C}$, and centrifuged at $9300 \times g$ for $5 \mathrm{~min}$. The cell pellet was diluted with $0.5 \%$ sodium chloride $(500 \mathrm{mg}$ in $100 \mathrm{~mL}$ sterile water) solution containing $10 \mu \mathrm{g} / \mathrm{mL}$ of crystal violet. The content was incubated at $37^{\circ} \mathrm{C}$ for $10 \mathrm{~min}$, shaken and centrifuged at $13,400 \times g$ for $15 \mathrm{~min}$. The absorbance of crystal violet in each supernatant was measured spectrophotometrically at $\mathrm{OD}_{590}[22]$. 


\subsection{Statistical Analysis}

Statistical significance was calculated by analysis of variance (Anova). Comparisons between means were carried out according to the Dunnett test. $p$ value $<0.05$ was considered as significant difference.

\section{Conclusions}

In correlating the observed effects of $R$. tomentosa extract, it is believed that the extract causing alteration in the bacterial membrane integrity along with immunostimulatory effects probably enhanced the killing activity of neutrophils against $E$. coli. Further studies in exploring exact mechanism involving effects of $R$. tomentosa extract on enterohaemorrhagic E. coli O157:H7 could be useful in the treatment of the organism.

Acknowledgments: The work was supported by the National Research University Project of Thailand's Office of the Higher Education Commission for Ph.D. scholarship and the TRF Senior Research Scholar (Grant No. RTA5880005), the Thailand Research Fund.

Author Contributions: J.H. and R.P. carried out the experiment with the plant extracts. J.H., R.P., and K.S.M. analyzed the data; S.P.V., K.S.M., and J.H. interpreted, discussed the results and prepared the manuscript.

Conflicts of Interest: The authors report no conflict of interest.

\section{References}

1. Griffin, P.M.; Tauxe, R.V. The epidemiology of infections caused by Escherichia coli O157:H7, other enterohemorrhagic E. coli, and the associated hemolytic uremic syndrome. Epidemiol. Rev. 1991, 13, 60-98. [PubMed]

2. Nguyen, Y.; Sperandio, V. Enterohemorrhagic E. coli (EHEC) pathogenesis. Front. Cell Infect. Microbiol. 2012, 2, 1-7. [CrossRef] [PubMed]

3. Smith, K.E.; Wilker, P.R.; Reiter, P.L.; Hedican, E.B.; Bender, J.B.; Hedberg, C.W. Antibiotic treatment of Escherichia coli $\mathrm{O} 157$ infection and the risk of hemolytic uremic syndrome, minnesota. Pediatr. Infect. Dis. J. 2012, 31, 37-41. [CrossRef] [PubMed]

4. Lim, J.Y.; Yoon, J.; Hovde, C.J.; Hovde, C.J. A brief overview of Escherichia coli O157:H7 and its plasmid O157. J. Microbiol. Biotechnol. 2010, 20, 5-14. [PubMed]

5. Voravuthikunchai, S.; Lortheeranuwat, A.; Jeeju, W.; Sririrak, T.; Phongpaichit, S.; Supawita, T. Effective medicinal plants against enterohaemorrhagic Escherichia coli O157:H7. J. Ethnopharmacol. 2004, 94, 49-54. [CrossRef] [PubMed]

6. Baskaran, S.A.; Venkitanarayanan, K. Plant-derived antimicrobials reduce E. coli O157:H7 virulence factors critical for colonization in cattle gastrointestinal tract in vitro. Biomed. Res. Int. 2014, 2014, 212395. [CrossRef]

7. Razali, F.N.; Ismail, A.; Abidin, N.Z.; Shuib, A.S. Stimulatory effects of polysaccharide fraction from Solanum nigrum on RAW 264.7 murine macrophage cells. PLoS ONE 2014, 9, e108988. [CrossRef] [PubMed]

8. Rafiul Haque, M.; Ansari, S.H.; Rashikh, A. Coffea arabica seed extract stimulate the cellular immune function and cyclophosphamide-induced immunosuppression in mice. Iran. J. Pharm. Res. 2013, 12, 101-108. [PubMed]

9. Chitemerere, T.A.; Mukanganyama, S. Evaluation of cell membrane integrity as a potential antimicrobial target for plant products. BMC Complement. Altern. Med. 2014, 14, 1-8. [CrossRef] [PubMed]

10. Ghule, B.V.; Yeole, P.G. In vitro and in vivo immunomodulatory activities of iridoids fraction from Barleria prionitis Linn. J. Ethnopharmacol. 2012, 141, 424-431. [CrossRef] [PubMed]

11. Wei, F. Manufacture of Traditional Chinese Medicine Composition for Treating Urinary Tract Infection (Gungxi Huahong Pharmaceutical Co., Ltd., People's Republic of China; Shanghai Fosun Pharmaceutical (Group) Co., Ltd.), Faming Zhuanli Shenqing Gongkai Shuomingshu. China Patent CN1853687, 1 November 2006.

12. Ong, H.C.; Nordiana, M. Malay ethno-medico botany in Machang, Kelantan, Malaysia. Fitoterapia 1999, 70, 502-513. [CrossRef] 
13. Wei, F. Manufacture of Oral Liquid Containing Traditional Chinese Medicine Extract for Treating Gynecopathy (Guangxi Huahong Pharmaceutical Co., Ltd., People's Republic of China; Shanghai Fosun Pharmaceutical (Group) Co., Ltd.), Faming Zhuanli Shenqing Gongkai Shuomingshu. China Patent CN1846715, 18 October 2006.

14. Lavanya, G.; Voravuthikunchai, S.P.; Towatana, N.H. Acetone extract from Rhodomyrtus tomentosa: A potent natural antioxidant. Evid. Based Complement. Altern. Med. 2012, 2012, 535479. [CrossRef] [PubMed]

15. Geetha, K.M.; Sridhar, C.; Murugan, V. Antioxidant and gastroprotective activities of R. tomentosa (Ait.) Hassk. Int. J. PharmTech. Res. 2010, 2, 283-291.

16. Limsuwan, S.; Trip, E.N.; Kouwen, T.R.; Piersma, S.; Hiranrat, A.; Mahabusarakam, W.; Voravuthikunchai, S.P.; van Dijl, J.M.; Kayser, O. Rhodomyrtone: A new candidate as natural antibacterial drug from Rhodomyrtus tomentosa. Phytomedicine 2009, 16, 645-651. [CrossRef] [PubMed]

17. Voravuthikunchai, S.P.; Dolah, S.; Charernjiratrakul, W. Control of Bacillus cereus in foods by R. tomentosa (Ait.) Hassk. leaf extract and its purified compound. J. Food Prot. 2010, 73, 1907-1912. [PubMed]

18. Saising, J.; Ongsakul, M.; Voravuthikunchai, S.P. R. tomentosa (Aiton) Hassk. ethanol extract and rhodomyrtone: A potential strategy for the treatment of biofilm-forming staphylococci. J. Med. Microbiol. 2011, 60, 1793-1800. [CrossRef] [PubMed]

19. Czuprynski, C.J.; Henson, P.M.; Campbell, P.A. Effect of dimethyl sulfoxide on the in vitro and in vivo bactericidal activity of human and mouse neutrophils and mononuclear phagocytes. Inflammation 1984, 8 , 181-191. [CrossRef] [PubMed]

20. Serafino, A.; Vallebona, P.S.; Andreola, F.; Zonfrillo, M.; Mercuri, L.; Federici, M.; Rasi, G.; Garaci, E.; Pierimarchi, P. Stimulatory effect of Eucalyptus essential oil on innate cell-mediated immune response. BMC Immunol. 2008, 9, 17. [CrossRef] [PubMed]

21. Yadav, M.K.; Chae, S.W.; Im, G.J.; Chung, J.W.; Song, J.J. Eugenol: A phyto-compound effective against methicillin-resistant and methicillin-sensitive Staphylococcus aureus clinical strain biofilms. PLoS ONE 2015, 10, e0119564. [CrossRef] [PubMed]

22. Li, N.; Luo, M.; Fu, Y.J.; Zu, Y.G.; Wang, W.; Zhang, L.; Yao, L.P.; Zhao, C.J.; Sun, Y. Effect of corilagin on membrane permeability of Escherichia coli, Staphylococcus aureus and Candida albicans. Phytother. Res. 2013, 27, 1517-1523. [PubMed]

23. Srisuwan, S.; Tongtawe, P.; Srimanote, P.; Voravuthikunchai, S.P. Rhodomyrtone modulates innate immune responses of THP-1 monocytes to assist in clearing methicillin-resistant Staphylococcus aureus. PLoS ONE 2014, 9, e110321. [CrossRef] [PubMed]

24. Strober, W. Trypan blue exclusion test of cell viability. In Current Protocols in Immunology; John Wiley \& Sons, Inc.: New York, NY, USA, 2001; pp. A.3B.1-A.3B.2.

Sample Availability: Samples of $R$. tomentosa extract are available from the authors.

(C) 2016 by the authors; licensee MDPI, Basel, Switzerland. This article is an open access article distributed under the terms and conditions of the Creative Commons Attribution (CC-BY) license (http://creativecommons.org/licenses/by/4.0/). 